\title{
KEPEMIMPINAN DI PERPUSTAKAAN BERDASARKAN EMOTIONAL INTELLIGENCE DALAM MENGHADAPI GLOBALISASI INFORMASI
}

\author{
Miftahunnisa' Igiriza*
}

Pengutipan: Igiriza, M. (2017). Kepemimpinan di perpustakaan berdasarkan emotional intelligence dalam menghadapi globalisasi informasi. Khizanah al-Hikmah : Jurnal Ilmu Perpustakaan, Informasi, dan Kearsipan, 5(1), 113-120 .

DOI: http://dx.doi.org/10.24252/kah.v5i1a10

*Mahasiswa Pascasarjana Ilmu Perpustakaan dan Informasi UIN Sunan Kalijaga Yogyakarta miftahunnisa.igiriza@gmail.com

\begin{abstract}
ABSTRAK
Pemimpin dalam sebuah kepemimpinan menjadi salah satu faktor pendukung maupun penghambat dari perkembangan organisasi dalam menghadapi fenomena perubahan yang kerap terjadi. Kemampuan kecerdasan emosional pemimpin memiliki peran yang penting bagi organisasi dan orang-orang yang bekerja pada organisasi tersebut. Tujuan penulisan ini yaitu untuk mengetahui bahwa kepemimpinan berdasarkan emotional intelligence dibutuhkan dalam gaya memimpin suatu organisasi seperti di perpustakaan yang menjadi pusat informasi. Artikel ini disusun berdasarkan studi literatur. Dapat diketahui, terjadinya globalisasi informasi, pola kepemimpinan yang baik di perpustakaan sangat dibutuhkan. Pola kepemimpinan berdasarkan emotional intelligence yang di dalamnya terdiri dari visioner, pembimbing, afiliatif, demokratis, penentu kecepatan, dan memerintah bisa menjadi pilihan pola kepemimpinan yang diterapkan di perpustakaan.
\end{abstract}

Kata Kunci: Kepemimpinan perpustakaan, kecerdasan emosional

\section{ABSTRACT}

Leader in a leadership became one of the factors as well as inhibiting the development of the organization in the face of the phenomenon of changes that often occur. Emotional intelligence abilities leaders have an important role for the organization and the people who work in these organizations. The purpose of this paper is to know that leadership is based on emotional intelligence needed to lead an organization like the style in which the library is a resource center. This article draws on literature studies. It can be seen, the globalization of information, a pattern of good leadership in the library is needed. The pattern of leadership based on the emotional intelligence of which consists of a visionary, coaching, affiliative, democratic, pacesetting, and commanding leadership style choice can be applied in the library.

Key words: Library leadership, emotional intelligence

\section{PENDAHULUAN}

Dewasa ini banyak sekali topik perbincangan mengenai globalisasi informasi. Munculnya globalisasi informasi memang tidak bisa dihindari.
Perkembangan teknologi yang begitu cepat menjadi faktor utama munculnya globalisasi. Globalisasi informasi mempunyai pengaruh yang sangat besar dalam kehidupan manusia pada saat ini. Seiring dengan berkembangnya zaman, 
globalisasi informasi bukan sekedar munculnya teknologi-teknologi canggih, globalisasi juga dipengaruhi oleh sosial, kultur ilmu pengetahuan, dan gaya hidup dari manusia itu sendiri.

Di era globalisasi informasi seperti saat ini, ilmu pengetahuan menjadi sangat penting, oleh sebab itu setiap individu harus banyak mencari dan mendapatkan informasi sebanyak mungkin dengan harapan menjadi modal luasnya pengetahuan dan wawasan serta pendalaman keilmuan yang sedang ditekuni. Hal ini juga dipengaruhi oleh tantangan di masa depan yang menuntut setiap manusia bisa menjadi produktif sehingga bisa ikut bersaing dalam dunia Internasional khususnya dalam mengahadapi Masyarakat Ekonomi Asean (MEA).

Perpustakaan sebagai lembaga yang memiliki tugas mengolah, menyimpan, mengemas dan mendistribusikan informasi saat ini dituntut untuk mampu beradaptasi di era globalisasi untuk memenuhi kebutuhan informasi masyarakat secara relevan, akurat, dan cepat. Keadaan tersebut membutuhkan kepemimpinan perpustakaan yang sadar dengan tuntunan zaman dan segera mengambil solusi untuk mengeksplorasi potensi informasi dan pengetahuan yang terdapat di lingkungannya serta mengembangkan sistem untuk penanganannya termasuk menyiapkan sumber daya manusia, organisasi, infrastruktur teknologi informasi, dan infrastruktur hukum yang diperlukan.

Perpustakaan sangat membutuhkan pemimpin yang sadar akan globalisasi informasi yang sudah terjadi dan perlunya solusi yang tepat untuk menghadapinya. Tetapi pada kenyataannya masih banyak fenomena kepemimpinan yang tidak jelas di perpustakaan, sehingga banyak perpustakaan berjalan kurang terarah dan tujuannya kurang jelas. Suatu organisasi seperti perpustakaan membutuhkan tujuan serta arah pengembangan perpustakaan dan pustakawan yang jelas. Kreativitas dan inovasi dari pustakawan sebaiknya di explore dan ditampung serta diberikan tempat agar peran mereka semakin terlihat dan mendapatkan apresiasi yang semakin meningkat.

Pemimpin dalam sebuah kepemimpinan menjadi salah satu faktor maupun penghambat dari perkembangan organisasi dalam menghadapi fenomena perubahan yang kerap terjadi di perpustakaan. Pemimpin yang baik memiliki kecerdasan emosional yang memadai (Labbaf, dkk., 2011).

Kemampuan kecerdasan emosional pemimpin memiliki peran yang penting bagi organisasi dan orang-orang yang bekerja pada organisasi tersebut sebagaimana pernyataan Daniel Goleman dalam bukunya yang sangat populer Emotional Intelligence yaitu "The leader has always acted as the group's emotional guide", bahwa seorang pemimpin menjadi pemandu emosi orang-orang dalam organisasi.

Oleh karena itu kepemimpinan berdasarkan emotional intelligence (kecerdasan emosional) dibutuhkan dalam gaya memimpin suatu organisasi seperti perpustakaan yang menjadi pusat informasi dengan era globalisasi informasi seperti pada saat ini.

\section{PEMBAHASAN LITERATUR}

\section{a. Globalisasi Informasi}

Globalisasi dimulai karena adanya kemajuan dalam bidang komunikasi, gaya hidup masyarakat yang serba digital, 
fakta ini seolah menegaskan bahwa masyarakat dunia telah memasuki era baru yang serba mobile, praktis, dan sangat personal. Budaya internet sebagai alat pencari semua informasi menjadi salah satu penanda kemajuan teknologi informasi dan gaya komunikasi yang tanpa batas, menyatukan dalam satu dunia baru yang disebut "dunia maya". Selain itu, penyebab globalisasi terjadi karena adanya kepentingan pasar antar industri internasional. Meskipun keadaan ini mampu membuat infrastruktur baru secara sosial kepada masyarakat itu sangat minim (Habernas, 2002, p. 149).

Globalisasi informasi timbul sebagai kekuatan yang mampu mempersempit ruang dan waktu akibat mengglobalnya perekonomian dunia. Berkaitan dengan arus informasi global, siapapun tidak dapat menolak kenyataan akan mengglobalnya arus informasi yang terakses, sehingga membentuk ranah yang disebut dengan masyarakat informasi global. Terdapat lima faktor penentu pembentuk masyarakat informasi, yaitu:

1) Kemajuan dalam bidang pendidikan,

2) Adanya perubahan dalam karakteristik pola kerja. Evolusi dalam pola kerja membuat orang mencari informasi atau pengetahuan tentang cara-cara paling efisien, efektif, praktis dan mudah untuk melakukan suatu pekerjaan,

3) Adanya perubahan penyebaran pengetahuan dari cara mulut ke mulut sampai pada penggunaan alat canggih yaitu personal komputer,

4) Adanya kemajuan dalam cara-cara orang informasi atau pengetahuan,

5) Adanya kemajuan dalam penciptaan alat-alat (tools) untuk menyebarkan dan mengakses informasi atau pengetahuan baru (Beni, 2002).

Tetapi masih ada juga informasi tertentu terdapat pembatasan akses, sehingga suatu informasi tidak dapat diakses oleh orang lain atau masyarakat luas seperti proteksi data tertentu jika menyinggung dengan masalah hukum pribadi atau privasi (Martin, 1995, pp. 200201). Terlepas dari aturan pembatasan akses informasi tertentu, sejatinya misi utama masyarakat informasi menurut Putu L. Pandit yaitu mewujudkan masyarakat yang sadar tentang pentingnya informasi, ilmu pengetahuan dan teknologi, terciptanya suatu layanan informasi yang terpadu, terkoordinasi dan terdokumentasi serta tersebarnya informasi ke masyarakat luas secara cepat, tepat dan bermanfaat (NS, 2005).

\section{b. Kepemimpinan}

Definisi tentang kepemimpinan sangat bervariasi. Pengertian kepemimpinan antara lain adalah kemampuan dan seni memperoleh hasil melalui kegiatan dengan mempengaruhi orang lain dalam rangka pencapaian tujuan yang telah ditentukan sebelumnya (Nawai, 2013, p. 152). Di dalam buku Gary Yukl yang berjudul Kepemimpinan Dalam Organisasi, ada beberapa pendapat tokoh tentang definisi kepemimpinan, antara lain:

1) Kepemimpinan adalah perilaku individu yang mengarahkan aktivitas kelompok untuk mencapai sasaran bersama (Hemphil dan Coons, 1957, hlm. 7).

2) Kepemimpinan adalah proses mempengaruhi aktivitas kelompok yang terorganisir untuk mencapai sasaran (Rauch dan Behling, 1984, hlm. 46). 
3) Kepemimpinan adalah proses memberikan tujuan (arahan yang berarti) ke usaha kolektif, yang menyebabkan adanya usaha yang dikeluarkan untuk mencapai tujuan (Jacobs dan Jaques, 1990, hlm. 281).

4) Kepemimpinan adalah proses untuk membuat orang memahami manfaat bekerja bersama orang lain, sehingga mereka paham dan mau melakukannya (Darth dan Palus, 1994, hlm. 4).

5) Kepemimpinan adalah cara mengartikulasikan visi, mewujudkan nilai, dan menciptakan lingkungan guna mencapai sesuatu (Richard dan Eagel, 1986, h. 4).

6) Kepemimpinan adalah kemampuan individu untuk mempengaruhi, memotivasi, dan membuat orang lain mampu memberikan kontribusinya demi efektivitas dan keberhasilan organiasi (House et. Al, 1999, hlm. 184) (Yuki, 2010, p. 4).

Selain itu, kepemimpinan juga meliputi proses memengaruhi dalam menentukan tujuan organisasi, memotivasi perilaku pengikut untuk mencapai tujuan, memengaruhi untuk memperbaiki kelompok dan budayanya (Rivai, 2010, p. 2). Dari beberapa definisi di atas dapat disimpulkan bahwa kepemimpinan merupakan kemampuan untuk mempengaruhi dan memotivasi suatu kelompok ke arah pencapaian tujuan bersama yang lebih baik.

\section{c. Emotional Intelligence}

Emotional intelligence atau yang biasa disebut dengan kecerdasan emosional adalah kecerdasan non kognitif, yaitu sesuatu yang ada di luar keahlian dan pengetahuan, artinya kemampuan untuk memahami diri sendiri dan orang lain, saat seseorang tersebut berhubungan dengan orang lain dan beradaptasi menghadapi lingkungannya (Dr. Christine Dreyfus, dalam Armstrong, 2003).

Dari definisi tersebut dapat diartikan bahwa kecerdasan emosional mencerminkan bagaimana pengetahuan diaplikasikan dan dikembangkan sepanjang hidup seseorang. Di sisi lain kecerdasan emosional juga dapat dipandang sebagai kompetensi (bersifat kognitif) jadi, meskipun bersifat insting dan emosional, tetapi tetap dapat dipelajari atau dilatih, dengan kata lain kompetensi emosional diperoleh seiring perkembangan kedewasaan seseorang.

Menurut Goleman (1999), kecerdasan emosional adalah kepastian untuk mengawali perasaan sendiri, untuk mengelola emosi dengan baik dalam diri sendiri dan dalam hubungan dengan orang lain. Sedang menurut Stephen P. Robin (2007), kecerdasan emosional adalah kemampuan, ketrampilan, kapabilitas dan kompetensi non kognitif yang mempengaruhi kemampuan seseorang untuk berhasil dalam menghadapi tuntutan dan tekanan lingkungannya. Emotional intelligence itu sendiri merupakan kemampuan seperti kemampuan untuk memotivasi diri sendiri dan bertahan menghadapi frustasi, mengendalikan dorongan hati dan tidak melebih-lebihkan kesenangan, mengatur suasana hati dan menjaga agar beban stres tidak melumpuhkan kemampuan berfikir, berempati dan berdo'a (Goleman, 2002, p. 45).

Kecerdasan emosional juga menjadi salah satu bidang yang menyelidiki dan menggali cara manusia mempergunakan keterampilan subjektif dan non kognitifnya agar dapat mengelola dan meningkatkan hubungan sosial dan kondisi kehidupan mereka (Chandra, 2010, p. 10). 


\section{d. Kepemimpinan Berdasarkan Emotional Intelligence}

Kepemimpinan berdasarkan emotional intelligence merupakan sebuah gaya kepemimpinan yang dipengaruhi oleh kecerdasan emosi yang ada pada individu masing-masing pada saat itu. Adapun gaya kepemimpinan berdasarkan emotional intelligence adalah sebagai berikut:

\section{1) Visioner}

Visioner merupakan pendekatan dengan meningkatkan orang akan tujuan yang lebih besar dari pekerjaan mereka, pemimpin visioner memberi arti yang lebih besar kepada pekerjaan sehari-hari yang bisa terasa membosankan. Para pekerja mengerti bahwa tujuan bersama itu selaras dengan minat terbaik mereka, dan hasilnya adalah yang menggugah (Goleman, 2002, p. 68). Pemimpin visioner paham bahwa penyebaran pengetahuan adalah rahasia menuju sukses, sehingga mereka membagikannya secara terbuka dan murah hati.

Action dari gaya ini yaitu menggerakkan orang-orang ke arah impian bersama. Sedangkan waktu penggunaannya yang tepat ketika perubahan membutuhkan visi baru, atau ketika dibutuhkan arah yang jelas (Goleman, 2002, p. 65).

\section{2) Pembimbing}

Setiap pemimpin perlu menjadi seorang pembimbing yang baik, tetapi para pemimpin cenderung jarang sekali menunjukkan gaya kepemimpinan pembimbing ini. Pembahasan dalam gaya kepemimpinan pembimbing ini lebih dari sekedar persoalan sehari-hari dan menjelajahi kehidupan seseorang, termasuk impian-impiannya, tujuan hidupnya, dan harapan kariernya. Meskipun gaya ini berfokus pada perkembangan perorangan, bukan pada pencapaian tujuan, tetapi gaya ini memprediksi adanya respon emosi yang positif dan hasil yang lebih baik. Gaya kepemimpinan pembimbing akan mendorong bawahannya untuk menetapkan tujuan jangka panjang, dan membantu mereka membuat konsep rencana untuk mencapai tujuan tersebut.

Action dari gaya ini yaitu menghubungkan apa yang diinginkan seseorang dengan sasaran organisasi. Sedangkan waktu penggunaannya yang tepat ketika membantu bawahan memperbaiki kinerjanya dengan membangun kemampuan jangka panjang.

\section{3) Afiliatif}

Gaya kepemimpinan ini membagi emosi secara terbuka, menghargai orangorang dan perasaan-perasaannya, tidak terlalu menekankan pencapaian hasil dan tujuan, dan lebih menekankan kebutuhan emosi bawahan. Meskipun kurang efektif sebagai pembangkit motivasi langsung terhadap kinerja, gaya afiliatif ini memiliki dampak positif yang luar biasa pada iklim emosi kelompok, seperti menghargai pegawai sebagai manusia, menawarkan dukungan emosional selama masa-masa sulit dalam kehidupan pribadinya, pemimpin ini membangun kesetiaan besar dan menguatkan ikatan.

Action dari gaya ini yaitu menciptakan harmoni dengan saling menghubungkan orang-orang. Sedangkan waktu penggunaannya yang tepat ketika menengahi benturan dalam tim, memotivasi di saat-saat yang menekan, atau menguatkan hubungan. 
4) Demokratis

Gaya kepemimpinan ini dengan meluangkan waktu untuk perorangan dan mendengarkan kepedulian bawahan di dalam pertemuan, pemimpin demokratis mempertahankan moral yang tinggi, dan dampak yang dihasilkan adalah iklim emosi yang positif di seluruh organisasi. Pendekatan demokratis akan sangat baik pada situasi dimana pemimpin tidak merasa pasti akan arah yang harus diambil dan membutuhkan ide dari bawahan yang mampu memberi ide. Bahkan jika seorang pemimpin memiliki visi yang kuat, gaya demokratis akan sangat bermanfaat untuk memancing ideide tentang cara terbaik bagaimana menerapkan visi tersebut atu bagaimana mendapatkan ide-ide baru tentang pelaksanaannya.

Action dari gaya ini yaitu menghargai masukan orang dan mendapatkan komitmen melalui partisipasi. Sedangkan waktu penggunaannya yang tepat ketika membangun persetujuan atau kesepakatan, atau mendapat masukan yang berharga dari bawahan.

\section{5) Penentu Kecepatan}

Gaya ini pemimpin memegang teguh dan melaksanakan standar kinerja yang tinggi. Ia bersikap obsesif bahwa segala sesuatu bisa dilakukan dengan lebih baik dan lebih cepat, serta meminta hal yang sama dari semua orang lain. Pemimpin yang bergaya penentu kecepatan sering kali tidak memberi garis petunjuk yang jelas, mengharapkan orang-orang sudah tahu apa yang harus dilakukan, pengikutnya seringkali harus menerka apa yang diinginkan oleh pemimpinnya. Akibatnya, ketika bawahan melihat bahwa pemimpinnya mendorong mereka terlalu keras, moral kerja mereka bisa runtuh atau yang lebih buruk lagi mereka merasa bahwa pemimpin tidak mepercayai bahwa mereka bisa menyelesaikan pekerjaan dengan cara mereka sendiri. Lebih dari itu, penentu kecepatan bisa begitu terfokus pada tujuan sehingga ia bisa tampak tidak peduli pada orang-orang yang sebenarnya ia andalkan untuk mencapai tujuan.

Action dari gaya ini yaitu menghadapi tantangan dan tujuan yang menarik. Sedangkan waktu penggunaannya yang tepat ketika ingin mendapatkan hasil berkualitas tinggi dari tim yang bermotivasi dan kompeten.

6) Memerintah (menenangkan rasa takut dengan memberi arah yang jelas di dalam keadaan darurat)

Gaya kepemimpinan ini menuntut kepatuhan-langsung pada perintahnya, tetapi tidak mau repot-repot menjelaskan alasan yang ada dibaliknya. Di samping kecenderungan negatifnya, gaya memerintah dan mengendalikan mempunyai tempat penting dalam perlengkapan pemimpin yang cerdas secara emosi jika digunakan dengan penuh pertimbangan dan tepat.

Action dari gaya ini yaitu menenangkan rasa takut dengan memberi arah yang jelas di dalam keadaan darurat. Sedangkan waktu penggunaannya yang tepat ketika saat kritis, untuk membangkitkan perubahan arah atau pada bawahan yang bermasalah (Goleman, 2002, pp. 65-93).

\section{e. Penerapan Kepemimpinan Berdasarkan Emotional Intellilegence di Perpustakaan}

Gaya kepemimpinan adalah suatu cara yang digunakan oleh seorang pemimpin dalam mempengaruhi perilaku orang lain. Gaya kepemimpinan merupakan norma 
perilaku yang dipergunakan oleh seseorang pada saat orang atau individu mencoba mempengaruhi perilaku orang lain. Masing-masing gaya tersebut memiliki keunggulan dan kelemahan. Seorang pemimpin akan menggunakan gaya kepemimpinan sesuai dengan kemampuannya dan kepribadiannya. Untuk penerapan gaya kepemimpinan berdasarkan emotional intelligence di perpustakaan adalah sebagai berikut :

\section{1) Gaya Visioner}

Pemimpin perpustakaan harus mempunyai pandangan ke depan tentang perkembangan perpustakaan di masa yang akan datang. Pemimpin perpustakaan sudah harus menyiapkan tindakan atau semacam program kerja jangka panjang yang disusun bersama dengan semua jajaran yang ada di perpustakaan terkait tentang kemajuan teknologi informasi dan globalisasi informasi.

\section{2) Gaya Pembimbing}

Pemimpin perpustakaan mengawasi dan mendampingi proses ketersediaan informasi di perpustakaan terkait dengan terjadinya ledakan informasi dan globalisasi informasi, serta memberi motivasi kepada bawahan-bawahannya sehingga tujuan perpustakaan dalam menyediakan informasi sesuai dengan kebutuhan dan harapan.

\section{3) Gaya Afiliatif}

Pemimpin perpustakaan menciptakan suasana harmonis di dalam dunia kerja, peka terhadap keadaan lingkungan sekitar, sehingga semangat kerja di lingkungan bawahan akan tumbuh maksimal dan berdampak pada kinerja degan banyaknya tuntutan di era globalisasi informasi.

\section{4) Gaya Demokratis}

Pemimpin perpustakaan memancing dan memberikan kesempatan kepada bawahan untuk memberikan kontribusi tentang ide-ide baru, saran untuk kemajuan perpustakaan dan program perpustakaan jangka panjang dalam menghadapi globalisasi informasi. Kegiatan ini dapat dilakukan pada saat rapat rutin.

\section{5) Gaya Penentu Kecepatan}

Pemimpin perpustakaan pada konteks tertentu harus otoriter (tegas) dalam pengambilan strategi yang berkaitan dalam perkembangan perpustakaan dan arus informasi global. Gaya kepemimpinan ini digunakan hanya sesekali dalam keadaan mendesak atau tertentu.

\section{6) Gaya Memerintah}

Pemimpin perpustakaan tegas dan bijaksana terutama dalam mengevaluasi job desk khususnya dalam menghadapi globalisasi informasi.

\section{KESIMPULAN}

Terjadinya globalisasi informasi, pola kepemimpinan yang baik di perpustakaan sangat dibutuhkan. Pola kepemimpinan berdasarkan emotional intelligence yang di dalamnya terdiri dari visioner, pembimbing, afiliatif, demokratis, penentu kecepatan, dan memerintah bisa menjadi pilihan pola kepemimpinan yang diterapkan di perpustakaan. 


\section{DAFTAR PUSTAKA}

Beni, R. (2002). Transisi Masyarakat Indonesia: Suatu Pemikiran Awal, dalam Sekapur Sirih Pendidikan Perpustakaan di Indonesia 19522002. KOMPAS, p. 50.

Chandra, G. (2010). Panduan Pendamping Kecerdasan Emosional. Mojokerto: Manuscript.

Goleman, D. (2002). Emotional Intelligence. Jakarta: Gramedia Pustaka Utama.

Habernas, J. (2002). Conversation about God and the World, Religion and Rationality. MIT Press.

Labbaf, \& dkk. (2011). The Impact of the Emotional Intelligence on Dimensions of Learning Organization: the Case of Isfahan University.

Business Research Interdisciplinary Business Research, Vol. 3 No. 5, 536-545.

Martin, W. J. (1995). The Information Society. Hampshire: Aslib Gower.

Nawai, I. (2013). Budaya Organisasi Kepemimpinan dan Kinerja. Jakarta: Prenadamedia.

NS, S. (2005). Tangung Jawab Perpustakaan: dalam Mengembangkan $\quad$ Masyarakat Informasi. Jakarta: Panta Rei.

Rivai, V. (2010). Kepemimpinan dan Perilaku Organisasi. Jakarta: Rajawali Press.

Yuki, G. (2010). Kepemimpinan dalam Organisasi. Jakarta: Indeks. 